\title{
The US experience in contracting out security and lessons for other countries
}

\author{
A experiência dos EUA na terceirização da segurança \\ e lições para outros países
}

http://dx.doi.org/10.1590/0034-7329201500112

THOMAS C. BRUNEAU*

Rev. Bras. Polít. Int. 58 (1): 230-248 [2015]

\section{Introduction}

There is an increasing reliance on private security contractors throughout the world. Already private security guards far outnumber uniformed police officers in many countries. In Latin America, for example, the ratio of private security guards to police officers is 6.7 to 1 in Guatemala and 4.9 to 1 in Brazil. ${ }^{1}$ There are indications that military personnel will to some degree be replaced by private contractors in several countries. In Argentina for example, the guards at the airports will be privatized rather than rely on the previous Air Force police. And, I know from requests I receive to discuss contracting out security from governments including Brazil, Nepal, and Portugal, that there is interest in the issue of contracting out security more generally. No country has gone further in contracting out security than the United States. While both government officials and scholars have repeatedly highlighted problems in contracting out security, these problems continue. I will draw upon the lessons I have learned from the US experience, particularly in Iraq, to draw what amounts to a cautionary tale regarding the use of private security contractors. The focus here is on private security contractors, those who carry weapons and most closely approximate the traditional roles of the uniformed military. More will be explained on these roles in the paper. This paper is based on data to which anyone energetic and interested can have access, largely from public and official US Government sources, my own research that included eight research trips to Washington, D.C. between 2009 and 2014, and which resulted in Anonymous.

\footnotetext{
* Department of National Security Affairs, Naval Postgraduate School, Monterey, CA, USA (tbruneau@nps.edu). 1 Organization of American States, Report on Citizen Security in the Americas 2012 (2012) Washington, DC: OAS Hemispheric Security Observatory, p. 139.
} 


\section{The US experience}

That the US is the world leader in the use of contractors can be seen in the Figure 1 below. $^{2}$

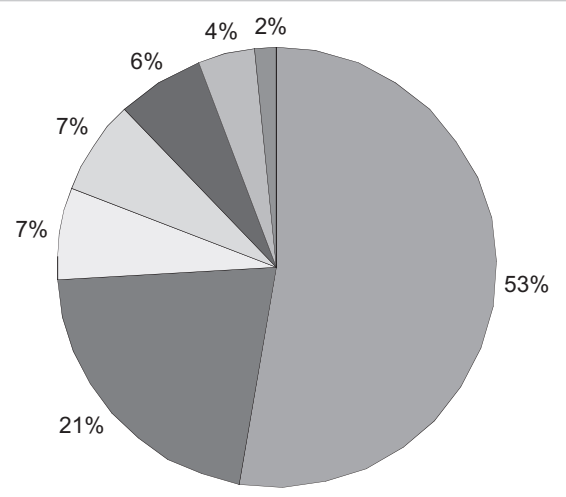

$\square$ Other

Figure 1. Geographical distribution of private security contractors.

The same data, displayed in Figure 2 shows that it is also as post-Cold War phenomenon with spikes during the wars in the Balkans and then in Afghanistan and Iraq. ${ }^{3}$

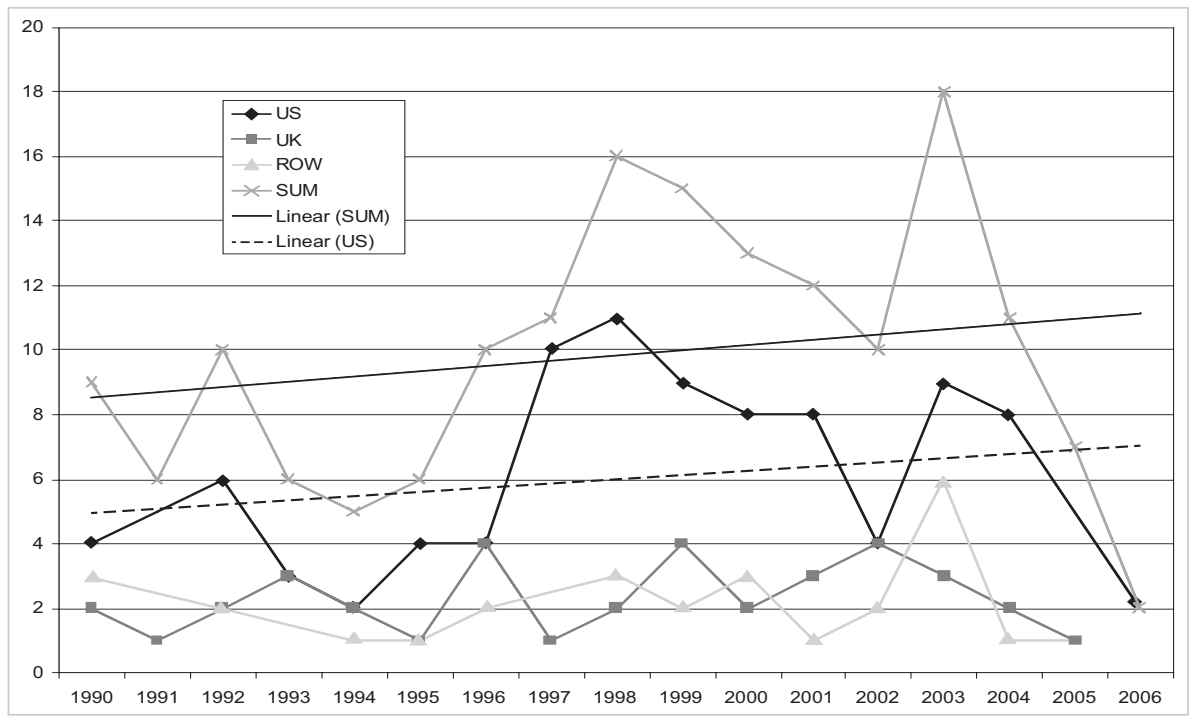

Figure 2. Founding of private security contractors.

2 Dew, Nicholas and Bryan Hudgens (2008). The Evolving Private Military Sector: A Survey, 21-22. Published in http://www.acquisitionresearch.org, p. 9. The data is derived from a survey sent to 550 private contracting firms.

3 Dew and Hudgens $(2008,8)$. 
But, that the use of contractors is an important phenomenon, there can be no doubt for in 2008 there were 190,000 contractors in the Iraq Theater compared to 200,000 uniformed military personnel. ${ }^{4}$

Despite the lack of reference to contractors in official documents and the main-line press, the use of private contractors continues today as an important phenomenon as is indicated by the fact that even after the departure of US troops from Iraq in December 2011, there still remained almost 11,000 private contractors. ${ }^{5}$ As a very respectable scholar researching and publishing on contracting out security states in a recent article. "... when the US withdrew its troops from Iraq in December 2011, the State Department sent in 5500 private security contractors to protect the embassy and American diplomatic interests there. To set this number in context, consider that it is roughly double the number of security contractors working for the State Department in Iraq prior to the withdrawal." 6 Even more telling, despite the lack of public attention in the current return by the US to fight the Islamic State in Iraq, the US Army Contracting Command published a "Sources Sought" in August 2014 for Security Assistance Mentors and Advisors Services in Iraq to "...focus on core process and systems which involve, but are not limited to administration, force development, procurement and acquisition, contracting, training management, public affairs, logistics, personnel management, professional development, communications, planning and operations, infrastructure management, intelligence and executive development." ${ }^{7}$

In sum, contracting out security remains a central characteristic of how the US operates, in combat and in general. To put the issue in perspective, as stated in a recent official report: "The Department of Defense (DOD) relies extensively on contractors to equip and support the US military in peacetime and during military operations, obligating more than US\$ 300 billion in contracts in FY 2013." ${ }^{8}$ To put this figure in perspective, the estimated total budget for DOD was US\$ 613.9 billion in FY 2013. ${ }^{9}$

4 Congressional Budget Office (CBO), (2008) Contractors' Support of US Operations in Iraq Washington, DC: $\mathrm{CBO}$, p. 13.

5 Schwartz, Moshe and Jennifer Church, (2013) Department of Defense's Use of Contractors to Support Military Operations: Background, Analysis, and Issues for Congress Congressional Research Service, p. 25. "Table A-2. Contractor Personnel and Troop Level in Iraq." These included private security contactors and others.

6 Dunigan, Molly (2014) The future of US military contracting: Current trends and future implications, International Journal Published online.

7 Federal Business Opportunities, Solicitation Number - W560MY-14-R-004. https://www.fbo.gov/index?s= opportunity\&mode=form\&id=2eec28ef1768665f2a6310916c50dff9\&tab=core\&_cview=0 accessed September 30, 2014. Emphasis added.

8 Schwartz, Moshe (2014) Summary "Defense Acquisition Reform: Background, Analysis and Issues for Congress" CRS Report for Congress.

9 For data on the overall DOD budget see Office of the Under Secretary of Defense (Comptroller) "National Defense Budget Estimated for FY 2013" available at http://comptroller.defense.gov/Portals/45/Documents/ defbudget/fy2013/FY13_Green_Book.pdf accessed January 22, 2015. 
The focus in this paper is on the PSCs because they are armed, thus most closely approximating what military personnel have done in the US in the past and what most armed forces in other countries do today. Since they are armed it is not surprising that the US Congress, have paid a great deal of attention to the PSCs. This focus is captured in the title of SEC. 862 of the National Defense Authorization Act (NDAA) for Fiscal Year 2008, Public Law 110-181 (5 December 2007): "Contractors Performing Private Security Functions in Areas of Combat Operations". ${ }^{10}$ The Special Inspector General for Iraq Reconstruction (SIGIR), which was founded by the US Congress in 2004 to audit the use of public funds in Iraq, published a "Comprehensive Plan for Audits of Private Security Contractors to Meet the Requirements of Section 842 of Public Law 110-181," updated on 8 May 2009, which provides detailed information on the PSCs and the audits and other studies being conducted on them. ${ }^{11}$ Moreover, the main focus at the Office of the Secretary of Defense (OSD), Assistant Deputy Under Secretary (Logistics \& Material Readiness/Program Support) is on implementing the guidance of Section 862.

As of 16 October 2008, SIGIR had identified seventy-seven individual PSC companies that provided security services to US agencies working in Iraq since 2003. In a May 2009 update of the report, SIGIR identified another sixteen, bringing the total to ninety-three companies that have provided physical security services in Iraq. The report estimates that since the war's inception in 2003 until early 2009, Department of Defense, Department of State, and United States Agency for International Development had spent US\$ 5.9 billion on contracts and subcontracts for PSCs. In interviews at SIGIR officials emphasized that the PSCs are extremely important in the overall reconstruction effort, and would likely become even more important as US forces withdrew, first from the major cities and finally from the country at the end of $2011 .{ }^{12}$ Considering the data provided above from Molly Dunigan on the 5,500 private security contractors remaining in Iraq after the departure of US troops, they were accurate.

A later SIGIR Report to Congress, in 2009, estimated that there were 25,500 private security personnel under contact in Iraq. ${ }^{13}$ SIGIR does not claim to have developed a precise definition of just what is a PSC. However, several federal agencies, including SIGIR, define a PSC in terms of the following four tasks or functions:

10 Contractor Performing Functions in Areas of Combat Operations, (2007) SEC. 862 of the National Defense Authorization Act (NDAA) for Fiscal Year 2008, Public Law 110-181.

11 Bowen, Stuart and David R. Warren (2009) Comprehensive Plan for Audits of Private Security Contractors to Meet the Requirements of Section 842 of Public Law 110-181, SIGIR.

12 Author interviews at SIGIR with the Deputy Director, the Assistant Inspector General for Audits, and several auditors, Arlington, Virginia, 26 February and 16 June 2009.

13 SIGIR, Quarterly Report to the United States Congress October 30, 2009, reports that as of September 30, 2009 there are 25,500 private security contractors in Iraq. There were, at the same time, 120,000 US forces. p. 47. 
- Static Security: protect fixed or static sites, such as housing areas, reconstruction work sites, or government buildings.

- Convoy Security: protect convoys traveling in Afghanistan and Iraq.

- Security Escorts: protect individuals traveling in unsecured areas in Afghanistan and Iraq.

- Personal Security Details - provide protective security to high-ranking individuals.

While these particular tasks or functions may not be associated with what are often referred to as "trigger pullers," they were previously carried out by personnel who were part of the highly-regulated, civilian-controlled military structure that I have described elsewhere. ${ }^{14}$ That is, they are the closest to the military in terms of being armed and protecting people, things, and places.

\section{The motivations to contract out}

There are several "drivers" or justifications for the contracting out phenomenon in the US. Some of these may apply in other countries. Relying on official sources, the following have been identified as the most important. ${ }^{15}$

First, an authoritative source to establish a baseline description of the general context for contacting out is the testimony of David M. Walker, then US Comptroller General, to the House Subcommittee on Readiness in March 2008. Walker offered a list of the factors that led federal agencies to outsource more and more services:

...limitations on the number of authorized full-time equivalent positions; unavailability of certain capabilities and expertise among federal employees; desire for operational flexibility; and the need for "surge" capacity. According to DOD and armed service official, several factors have contributed to the department's increased use of contractors for support services: (1) the increased requirements associated with the Global War on Terrorism and other contingencies; (2) policy to rely on the private sector for needed commercial services that are not inherently governmental in nature; and (3) DOD initiatives, such as competitive sourcing and utility privatization programs. ${ }^{16}$

These are ongoing and long-term motivations.

Second, with the all-volunteer force, private security contractors are thought by informed experts to be necessary. At the end of the Cold War, the US Army

14 Specifically in Anonymous.

15 Dew and Hudgens (2008) pp. 44-50. Singer, P.W. (2003) Corporate Warriors: The Rise of the Privatized Military Industry Ithaca: Cornell University Press, dedicates a chapter to this topic, 4, "Why Security Has Been Privatized", pp. 49-70.

16 Walker, David M. (2008) Comptroller General of the United States, Before the Subcommittee on Readiness, Committee on Armed Services, House of Representatives, GAO-08-572T: 4-5. 
went from 732,000 active personnel in 1990 to 408,000 in 1997; for the three services, including the Marines, the numbers were 2,043,705 in 1990, to 1,438,562 in 1997. As of August 2009, with two wars waging, the size of the US Army stood at $552,425 .{ }^{17} \mathrm{~A}$ number of contractor proponents highlighted to me the personnel shortage to explain the growth of the PSCs.

Third, Secretary of Defense Donald Rumsfeld (2001-2006) wanted to demonstrate that the Iraq invasion and pacification could be accomplished with a lean force, and that technology would be a sufficient force multiplier. Such a success would justify his policies promoting defense "transformation" over a traditional build-up of forces, policies that were encouraged by Rumsfeld and others in the George W. Bush Administration. As Richard N. Haass states, the invasion of Iraq in 2003 was a "war of choice" rather than of necessity as its proponents claimed. ${ }^{18}$ Whereas the United States deployed 500, 000 troops in the 1991 war against Iraq, in line with the Powell Doctrine premise of using overwhelming force to achieve a clear goal, the 2003 invasion kept troop levels to about 150,000. General Eric Shinseki, Army Chief of Staff, disagreed with this policy while being questioned before Congress. Shortly thereafter Secretary of Defense Rumsfeld announced Shinseki's replacement, about eighteen months before his scheduled retirement. Rumsfeld ignored military advice, and other military leaders did not push back. ${ }^{19}$ In interviews, security contractors emphasize the security vacuum that they have been employed to fill, but the vacuum appears to be a result of deliberate policy rather than exigency.

In sum, there are at least three major reasons for the growth in contracting in general, and security in particular, as demonstrated in Figures 1 and 2 and Table 1 above. The result was chaotic as Secretary Rumsfeld's successor, Robert M. Gates, would write. "As the contractor presence developed in Iraq after the original invasion, there was no plan, no structure, no oversight, and no coordination. The contractors' role grew willy-nilly as each US department or agency contracted with them independently, their number eventually climbing to some 150,000.”20

While other countries' armed forces may not be engaged in combat as are US forces, there is still a strong appeal to the logic of contracting out. In theory, at least, contractors should be cheaper than professional military personnel in that

17 The data for 1990 is from "Selected Manpower Statistics Fiscal Year 1990," (AD-A235 849), issued by Washington Headquarters Services, Directorate for Information Operations and Reports, Department of Defense. Data for 1997 and 2009 are found at: http://siadapp.dmdc.osd.mil/personnel/MILITARY/history/tab9

18 Haass, Richard N. (2009) War of Necessity War of Choice: A Memoir of Two Iraq Wars New York: Simon \& Schuster.

19 Richard Haass refers to "...the effective silencing of the Joint Chiefs of Staff by Secretary of Defense Donald Rumsfeld.”. Haass, War of Necessity, pp. 18-19. This key point has been dealt with extensively in credible sources. Joseph Collins lists ten "Errors in Decisionmaking and Execution," of which eight concern lack of manpower. See Collins, Joseph J. (2008) Choosing War: The Decision to Invade Iraq and Its Aftermath, Occasional Paper, Institute for National Strategic Studies, National Defense University, p. 16.

20 Gates, Robert (2014) Duty: Memoirs of a Secretary at War New York: Alfred A. Knopf, p. 224. 
they can be let go when there is no longer a need for them, and none of the additional costs, such as health benefits, dependents' allowances, pensions, and the like are required. ${ }^{21}$ It is important to stress that it is mainly for these theoretical reasons that contracting out is strongly encouraged in the US not only under Republican but also Democratic administrations.

\section{Contracting out is not only legal, but strongly encouraged in the US}

Many outsiders, and critics, do not seem to realize that contracting out is not only legal in the US, but in fact strongly encouraged by laws and policies from President Ronald Reagan (1981-1989) until the present. A 2008 Congressional Research Service (CRS) report gives a sense of what is involved, and the extensive legal basis, for government contracting:

Sometimes called contracting out, "outsourcing" refers to an agency engaging a private firm to perform an agency function or provide a service. ....Federal outsourcing policy is governed by the FAR [Federal Acquisition Regulation] and the Federal Activities Inventory Reform (FAIR) Act of 1998 (P.L. 105-270). FAIR requires agencies to produce inventories of "commercial activities" - those that are not "inherently governmental" and able to be acquired from the private sector - that may be put up for competitive sourcing. OMB's Circular A-76 provides agencies with specific directions for undertaking competitive sourcing. ${ }^{22}$

The Office of Management and Budget (OMB) Circular A-76 provides the legal basis for outsourcing. ${ }^{23}$ There is an extensive literature by practitioners on this topic, which conveys a sense of the extremely pro-privatization environment of the US government. ${ }^{24}$ There is a "dialogue of the deaf" on this issue. Social scientists, some journalists, and sectors of the general public see contracting out functions in national security and defense as anomalous, even somehow shady, whereas those within government view it as standard operating procedure. And, since almost one half of the DOD budget is currently contracted out, it indeed is.

21 It is worth noting that the Brazilian lower house, the Câmara, approved a bill in January 2015 to outsource labor. See http://www1.folha.uol.com.br/fsp/opiniao/215181-capital-sobe-trabalho-desce.shtml

22 Kosar, Kevin R. (2006) Contracting for Services (Outsourcing) in Privatization and the Federal Government: An Introduction Washington, DC: Congressional Research Service, p. 15.

23 Luckey, John R. (2003) OMB Circular A-76: Explanation and Discussion of the Recently Revised Federal Outsourcing Policy, CRS Report for Congress, Washington, D.C., updated 10 September 2003.

24 See for example, Donahue, John D. (1989) The Privatization Decision: Public Ends, Private Means New York: Basic Books and Light, Paul C. (2008) A Government Ill Executed: The Decline of the Federal Service and How to Reverse It Cambridge: Harvard University Press. 


\section{Awareness of problems in contracting out in recent conflicts}

In the US the general issue of the use of public funds, and especially the utilization of contractors, became a very public and polemic issue which motivated the US Congress to not only hold hearings and pass laws to regulate the use of contractors in Iraq and Afghanistan, but also created organizations to focus specifically on the waste of very large sums of money. As noted above, the Congress created SIGIR, and despite efforts by the George W. Bush administration to shut it down, SIGIR continued until 2013 (when there were no more public funds to audit in Iraq). Between its creation in 2004 and its final Report in September 2013, the SIGIR dealt with all imaginable topics surrounding the use of the US\$ 60 billion of US funds allocated by the US Congress for the reconstruction of Iraq. The focus on contractors, including private security firms, was a central element of SIGIR's work. ${ }^{25}$

Even more specifically regarding contracting out, in the face of scandals, fraud, and other problems, the U. S. Congress created in 2008 the Commission on War Time Contracting to examine contracting out in Iraq and Afghanistan. In their final report Transforming Wartime Contracting: Controlling costs, reducing risks, of August 2011, the Commission stated that at least US\$ 31 billion, and possibly as much as US\$ 60 billion had been lost to contract waste and fraud in operations in Iraq and Afghanistan. ${ }^{26}$

Despite the widespread awareness of problems, and the current "sources sought" from the Army Contracting Command for contractors to go to Iraq, the problems continue. A recent official document puts it this way: "Congress and the executive branch have long been frustrated with waste, mismanagement, and fraud in defense acquisitions and have spent significant resources attempting to reform and improve the process. These frustrations have led to numerous efforts to improve defense acquisitions. Since the end of World War II, every Administration and virtually every Secretary of Defense has embarked on an acquisition reform effort. Yet despite these efforts, cost overruns, schedule delays, and performance shortfalls in acquisitions programs persist." 27

25 The SIGIR Final Report to the United States Congress, dated September 9, 2013, is available at www.sigir.mil. Accessed January 14, 2015. The Special Inspector General for Afghan Reconstruction (SIGAR) still continues. 26 The Final Report to Congress of the Commission on Wartime Contracting in Iraq and Afghanistan, Transforming Wartime Contracting: Controlling costs, reducing risks dated August 2011 is available at www. wartimecontracting.gov. Accessed January 14, 2015.

27 Schwartz, Moshe (2014) Defense Acquisition Reform: Background, Analysis, and Issues for Congress CRS Report, (R 43566), p. i. 


\section{Implications for National Security and Defense of contracting out security}

The most recent Congressional Research Service Report on the topic of contracting out states, in the first sentences of the Introduction: "The Department of Defense (DOD) has long relied on contractors to provide the US military with a wide range of goods and services, including weapons, food, and operational support. Without contractor support, the United States would currently be unable to arm and field and effective fighting force. ${ }^{28}$ As it is certain that contracting out national security and defense is here to stay, what, then, are some of the implications of this phenomenon? Utilizing our framework for analysis of civil-military relations and applying it to the PSCs, the results are displayed in Table $2 .{ }^{29}$

Table 1. Institutional dimensions of public and private national security and defense.

\begin{tabular}{|l|l|l|l|}
\hline $\begin{array}{l}\text { Civil-military } \\
\text { relations }\end{array}$ & $\begin{array}{l}\text { Eonitoring and oversight } \\
\text { by full spectrum of } \\
\text { institutional mechanisms }\end{array}$ & $\begin{array}{l}\text { Control exercised by full } \\
\text { spectrum of institutions, } \\
\text { oversight mechanisms, } \\
\text { and professional } \\
\text { education }\end{array}$ & $\begin{array}{l}\text { Problematic due to } \\
\text { lack of strategy and } \\
\text { weakness of interagency } \\
\text { institutions }\end{array}$ \\
\hline $\begin{array}{l}\text { Private } \\
\text { security } \\
\text { contractors }\end{array}$ & Same as above & $\begin{array}{l}\text { Minimal control due } \\
\text { to uncertain concept of } \\
\text { inherently governmental } \\
\text { functions and sketchy } \\
\text { legal controls }\end{array}$ & $\begin{array}{l}\text { Problematic due to lack } \\
\text { of doctrine to include } \\
\text { PSCs and absence or } \\
\text { shortage of contracting }\end{array}$ \\
\hline
\end{tabular}

In reviewing these three dimensions - efficiency, control, and effectivenesswith regard to the US may allow other countries to better prepare for contractingout than the US was and still is.

Efficiency, which in my framework is essentially having functioning institutions to investigate and audit where resources go and how they are used, is not currently a problem with regard to the private security contractors. The federal institutions and mechanisms that carry out audit and investigation functions specifically to monitor the efficiency of PSCs are robust. Among many initiatives geared toward improving transparency in Iraq, Congress directed the Congressional Research Service (CRS) to undertake extensive reporting, including

28 Schwartz, Moshe and Wendy Ginsburg, and John F. Sargent Jr, (2015) Defense Acquisitions: How and Where DOD Spends Its Contracting Dollars CRS Report, (R44010), p. 1.

29 This framework is explained and illustrated in Anonymous. 
a "Congressional Oversight Manual;" 30 the Congressional Budget Office (CBO) to assess budgets and analyze the PSCs' contracts; the Government Accountability Office (GAO) to study all relevant aspects of the contracting phenomenon; and most importantly and provocatively, kept SIGIR funded. ${ }^{31}$

Control As the scope of contracting out expanded in Iraq, and scandals were made public by SIGIR, the media, and non-governmental organizations (NGOs), there developed a sense that the PSCs had been allowed to expand their activities into what were previously considered "inherently governmental functions". This concern was palpable in many personal interviews of the author with very senior policy-makers. The issue was raised publicly by members of the US Congress during the last months of 2008, where the ensuing political battle over the definition of inherently governmental exposed some of the different powers and funding sources of different sectors of the security contracting "industry".

That legislative debate, and the fact that the new administration coming into office on 20 January 2009 included not only President Barack Obama but also Secretary of State Hilary Clinton, both of whom had weighed in as senators in that debate on the side of tightening up the definition of "inherently governmental functions," meant that the issue would continue to have a high profile. Consequently, in mid-2009, the Office of Management and Budget (OMB) was tasked with delimiting inherently governmental functions, for which it held a public discussion in June. However, and important to understand concerning the politics of this issue, once contractors took on the missions that were previously inherently governmental, and developed supporters in government through the use of campaign funds and lobbyists, it was extremely difficult to turn the trend around. Proof of this point is that the most recent CRS report on Inherently Governmental Functions, of 23 December 2014, states boldly that there are two primary definitions of "inherently governmental functions" and in the four pages of tables at the end of the report demonstrates that there in fact four different definitions. ${ }^{32}$

If an area of governmental responsibility that originally was considered to be inherently governmental has been opened up to the PSCs, then what kind of control can be exerted to be sure they are acting in the best interests of the country? It is clearly not the robust set of institutions, oversight, and professional norms that apply to the uniformed military - they do not apply even to those contractors

30 Kaiser, Frederick M. and Walter J. Oleszek, T.J. Halstead, Norton Rosenberg, and Todd B. Tatelman, (2007) Congressional Oversight Manual, CRS Report for Congress (RL 30240). The manual was updated, and republished on 19 December 2014. It is CRS RL30240.

31 The GAO details their instruction to study PSCs in "MILITARY OPERATIONS. High-Level DOD Action Needed to Address Long-standing Problems with Management and Oversight of Contractors Supporting Deployed Forces," Government Accountability Office (GAO) Report to Congressional Committees (GAO-07145), December 2006, updated from 2003: 3.

32 Manuel, Kate M. (2014) Definitions of "Inherently Governmental Function" in Federal Procurement Law and Guidance, CRS Report for Congress; the tables are pp. 22-25. 
who carry out what seem to be military functions. Some experts, especially non-US sources, look to legal controls through enforcement of or modifications of existing law. ${ }^{33}$ While this appears promising in theory, in fact the legal basis for reigning in the PSCs is also problematic.

The legal bases for regulating and controlling the PSCs are dealt with in studies by the CBO, CRS, GAO, and by contract law specialists in a number of publications. Even so, it is very difficult to determine the current legal status of contractors, including the PSCs. Under international law, contractors and other civilians working with the military are classified as civilian non-combatants. The application of international laws of armed conflict, including under the 1977 Protocol I to the Geneva Convention on mercenaries, however, is ambiguous, according to this CRS report and others. ${ }^{34}$

Under US law, "US contractor personnel and other US civilian employees in Iraq may be subject to prosecution in US courts. Additionally, persons who are "employed by or accompanying the armed forces" overseas may be prosecuted under the Military Extraterritorial Jurisdiction Act of 2000 (MEJA) or, in some cases, the Uniform Code of Military Justice (UCMJ). ${ }^{35}$ But even with this statutory authority, some contractors "might fall outside the jurisdiction of US criminal law, even though the United States is responsible for their conduct as a matter of state responsibility under international law and despite that such conduct might interfere with the ability of the Multi-National Forces in Iraq to carry out its US mandate." 36

In interviews with Mr. Jeff Green, who had been Counsel to the Committee on Armed Services in the US House of Representatives and then President of his own lobbying firm and Doug Brooks, then President of the International Peace Operations Association (IPOA), in mid-June 2009, they concurred with this assessment. Brooks noted that while initially he and the members of IPOA were concerned with the SOFA, its implementation has worked out better than expected. The only thing that becomes apparent from these sources is that at present clear control is exercised over the PSCs neither by international law nor US law. Because the latter system is based on precedent, cases such as the Blackwater shootings in

33 See for example, Alexandra, Andrew, Deane-Peter Baker and Marina Caparini, eds. (2008) Private Military and Security Companies: Ethics, policies and civil-military relations London and New York: Routledge; and more recently, Sheehy, Benedict, Jackson Maogoto, and Virginia Newell, (2009) Legal Control of the Private Military Corporation Basingstoke: Palgrave Macmillan.

34 For example, the Montreux Document of 17 September 2008 resulted from a meeting of seventeen countries regarding rules and good practices relating to private military and security companies operating in armed conflicts and relates to the Status of the Protocols Additional to the Geneva Conventions of 1949, and to the protection of victims of armed conflicts. The document "...contains a set of over 70 good practices designed to assist States in complying with these obligations. Neither parts are legally binding, nor are they intended to legitimize the use of PMSCs in any particular circumstance." Summary of United Nations "General Assembly Security Council," (A/63/467-S/2008/636), 6 October 2008.

35 Elsea, Jennifer K. Moshe Schwartz, and Kennon H. Nakamura, (2008) p. 20.

36 Ibid. 
Nisour Square in Bagdad on September 16, 2007 have to work their way through the appeals courts to reach some determination of how existing laws apply, and possibly to point the way toward additional legislation. ${ }^{37}$

Contracting firms are quick to argue that they are more effective than government agencies. And, since setting the bar with this comparison is extremely low, they may be right. However, one cannot look only at one contract but the overall situation of contracting out to understand their effectiveness. Based on research comparatively and in the US, we have developed a concept (within the framework displayed in Table 2), which we apply to the armed forces, the following three requirements for effectiveness: a plan, institutions to implement the plan, and adequate resources (financial and human) to reach the goal.

Consequently, the first question to ask is, is there a plan that defines, coordinates, and implements a strategy for the use of contractors in support of military operations? Even if the combat commander in the field had a strategic vision of how to fight in the theater, as he must, he probably does not have control over the contactors operating in the theater, or have a way to include them in his strategic vision. As an August 2008 CBO report, states:

Although military commanders can directly control the actions of military personnel and government civilians, their control over individual contractor personnel is less direct [...]. In practice that authority [laws and regulations of the United States] enables the military commander to allocate the personnel under his or her command among any number of tasks those personnel are able and trained to do. The military commander may also request that additional personnel be reassigned from other parts of the government if necessary. By contrast, the duties of contractor personnel are set out in a fixed written contract $[\ldots]$. The military commander generally lacks the authority either to increase the scope (dollar value) of the contract or to change the contractor's duties except in ways anticipated in the contract language. [...] The military commander has less direct authority over the actions of contractor employees than over military or government civilian subordinates. ${ }^{38}$

Currently, there is no doctrine that compels integration of the contractors into a military commander's strategy. Even once formulated, however, this doctrine will have to be adopted and implemented by the three separate services that individually have the authority to recruit, train, and equip the armed forces. Indeed there are now some indications of this awareness, but as it is a service responsibility, and it takes a VERY long time to formulate, let along implement, a doctrine. As of

37 On October 22, 2014 a jury in the Federal District Court in Washington, D.C. found four former Blackwater private security guards guilty in the deaths of 17 Iraqi civilians in Nisour Square in 2007. This was the first conviction of private security guards in the US court system. In April 2015 the four were sentences to terms ranging from 30 years to life imprisonment.

38 “Contractors' Support of US Operations in Iraq," CBO Paper, August 2008: 20. 
late 2011 the United States Army has published a doctrine, Operational Contract Support Planning and Management, signed by General Martin E. Dempsey, at that time Chief of Staff of the Army. It will, however, take some time before this doctrine is assimilated by the troops in the field, including the commanders. ${ }^{39}$

To be effective a security strategy requires institutions to implement it. What kinds of institutions are there, if any, to coordinate the contractors? The Gansler Commission Report, named for its chairman, The Honorable Jacques Gansler who was Under Secretary of Defense for Acquisition, Technology and Logistics during the Clinton Administration and who currently holds a named chair for Public Policy and Private Enterprise at the University of Maryland identifies problems with complexity, an insufficient focus on post-award contract management, inadequate organization and inadequate lines of responsibility to facilitate contracting. ${ }^{40}$ Under the heading, "Extremely Poor Interagency Operations," the report finds that there is a lack of institutional orientation and functional inter-agency process in all of the areas listed above. ${ }^{41}$ The following quotes, from this section of the report, elaborate these points, rearranged slightly here to follow the line of my argument.

In the Cold War environment, it was not envisioned there would be other Departments or Agencies engaged so much on the field of conflict. Today, the military commander who is supported by a "joint" contracting organization actually has a disparate group of well-meaning professionals sitting side-by-side applying different rules to the same situation [...]. While it is recognized that the State Department, Justice, Commerce, Treasury, et al. bring impressive tool kits, which represent some of the most effective tools America has to offer and are critically essential to nation-building, in the Cold War era, these players only entered after the battlefield was relatively secure. They were not the integrated partners which successful expeditionary operations may require. ${ }^{42}$

As the contractors are not under direct control of the commander, but are necessary for the success of his plan or strategy, the absence of coordination or an inter-agency process is especially important. All the sources I consulted, both written and in personal interviews, conclude that there is no overall plan or strategy within the DOD to integrate the contractors into an effective whole, nor is there an institutional mechanism to coordinate their work. The congressional staffers, academics, and GAO personnel interviewed all emphasized this critical weakness.

The next question to ask is one regarding human resources (and not financial resources as the US poured money into the campaigns in Iraq and Afghanistan),

39 US Army, "Operational Contract Support Planning and Management," Army Regulation 715-9Washington, DC: Headquarters of the Army June 20, 2011. Available at http://www.apd.army.mil/pdffiles/r715_9.pdf

40 Gansler Commission Report "Urgent Reform Required: Army Expeditionary Contracting," report of the Commission on Army Acquisition and Program Management in Expeditionary Operations, 31 October 2007.

41 Gansler Commission Report: $39-46$

42 Ibid.: 45-6 
and the question is what quantity and quality of personnel are in place to award and, even more important, oversee or monitor the contracts? ${ }^{43}$ This, however, is an institutional issue that is very difficult to remedy. The scope of the problem is daunting. The Gansler Commission report directly addresses the fact that the contract management workforce has not increased despite a seven-fold increase in the workload.

In 1990, the Army had approximately 10,000 people in contracting. This was reduced to approximately 5,500, where it has remained relatively constant since 1996. [...] yet both the number of contract actions (workload) and the dollar value of procurements (an indicator of complexity) have dramatically increased in the past decade while the contracting workforce has remained constant. The dollar value of Army contracts has increased 331 percent from US\$23.3 billion in 1992 to US\$ 100.6 billion in 2006, while the number of Army contract actions increased 654 percent from approximately 52,900 to 398,700 over the same period. ${ }^{44}$

Furthermore, the overwhelming majority of contract managers are civilians; out of a total of 5,800, there are only 279 military personnel doing this job. ${ }^{45}$ This is extremely important as military personnel can be deployed much more easily than can civilians, and the report goes into some detail on why it is difficult to deploy civilians. ${ }^{46}$ It means that the contract managers were not in Iraq, or Afghanistan, but rather in the US. The background to this situation of few military contracting officers is found in the reduction of military forces at the end of the Cold War in the 1990s. While overall US Army forces, for example, were reduced $32 \%$ from 732,000 in 1990 to 499,301 by 2003 , the ranks of contracting officers were reduced $45 \%$ from 10,000 to 5,500, including the elimination of all flag and general officer positions during the same period. ${ }^{47}$

43 According to Belasco, Amy (2014) The Cost of Iraq, Afghanistan, and Other Global War on Terror Operations Since 9/11, Congressional Research Report (RL33110), p. i. the total sum is \$ 1.6 trillion of which \$ 815 billion was for the war in Iraq.

44 Gansler Commission Report: 30. See also Schwartz, Moshe (2008) Training the Military to Manage Contractors During Expeditionary Operations: Overview and Options for Congress, CRS Report for Congress, p. 1, Figure 1. "However, while a number of contracting officers and other acquisition officials are in Iraq, most of DOD's acquisition workforce is generally not deployed or embedded with the military during expeditionary operations. As the number of contactors in the area of operations has increased, the operational force - the service men and women in the field - increasingly rely on, interact with, and are responsible for managing contractors. Yet, a number of military commanders and service members have indicated they did not get adequate information regarding the extent of contractor support in Iraq and did not receive enough pre-deployment training to prepare them to manage or work with contractors." Schwartz: 3. Schwartz draws heavily on Walker, David M. (2008) Defense Management: DOD Needs to Reexamine Its Extensive Reliance on Contractors and Continue to Improve Management and Oversight, Testimony Before the Subcommittee on Readiness, Committee on Armed Services, House of Representatives. (GAO-08-572T.

45 Gansler 35, table 9.

46 Ibid. 36-7.

47 Gansler Commission Report: 30. 
Given this chronic shortage of personnel, who then oversees the fulfillment and completion of the contract? This is the contracting officer representative, or COR.

There is agreement among sources on the lack of preparation for CORs, and the unreasonable multi-tasking expected of them. The Gansler Report is very critical of the CORs as an institutional mechanism for oversight.

Contracting Officer's Representatives (CORs), who are an essential part of contract management, are at best a "pick-up game" in-theater. CORs represent the "last tactical mile" of expeditionary contracting. However, CORs are assigned as contract managers/administrators as an "extra duty," requiring no experience. A COR is often a young Soldier who does not have any experience as a COR. [...] Although being a COR would ideally be a career-enhancing duty, the COR assignment is often used to send a young Soldier to the other side of the base when a commander does not want to have to deal with the person. Additionally, little, if any, training is provided. To further compound matters, generally all COR training is geared for a low-operations, low risk tempo, so it is barely adequate. Despite this, there are still too few CORs. Moreover, COR turnover is high, frequently leaving many gaps in contract coverage. ${ }^{48}$

In June 2003, GAO issued a comprehensive analysis of problems with DoD management and oversight of contactors that support deployed forces, and released a follow-on report to Congress in December 2006. ${ }^{49}$ In the updated report, William M. Solis, GAO's director of Defense Capabilities and Management, noted that GAO began to report in 1997 on shortcomings in DoD's management and training of contractor support to deployed forces, and took on the current study due to the increased use of contractors, and ongoing Congressional interest: “...GAO's objective was to determine the extent to which DOD has improved its management and oversight of contractors supporting deployed force since our 2003 report." ${ }^{\prime 0}$ This preface then lists four areas as examples of ongoing problems with contracting, all of which fall within the three analytical dimensions outlined above: planning, institutions, and resources. What is clear is that the problems identified in the report of June 2003 still applied in December 2006. ${ }^{51}$

The report also addresses persistent problems with insufficient resources to conduct oversight:

48 Gansler Commission Report: 43.

49 Solis, William M. Director, (2006) Defense Capabilities and Management, "MILITARY OPERATIONS: High-Level DOD Action Needed to Address Long-standing Problems with Management and Oversight of Contractors Supporting Deployed Forces" GAO report to Congress (GAO-07-145).

50 Ibid.: Highlights (no page number).

51 Ibid: Highlights, Military Operations (no page numbers). 
DOD continues to not have adequate contractor oversight personnel at deployed locations, precluding its ability to obtain reasonable assurance that contractors are meeting contract requirements efficiently and effectively at each location where work is being performed. While a lack of adequate contract oversight personnel is a DOD-wide problem, lacking adequate personnel in more demanding contacting environments in deployed locations presents unique difficulties. ${ }^{52}$

Training is another aspect of the resource dimension:

Military personnel continue to receive limited or no training on the use of contractors as part of their pre-deployment training or professional military education. The lack of training hinders the ability of military commanders to adequately plan for the use of contractor support and inhibits the ability of contract oversight personnel to manage and oversee contractors in deployed locations. Despite DOD's concurrence with our previous recommendations to improve such training, we found no standard to ensure information about contractor support is incorporated in pre-deployment training. ${ }^{53}$

Although resources are the main issue in this observation, it also has implications for both planning and institution-building in that without training to manage and oversee the contractors, a commander and his staff cannot coordinate the contractors' work with the command's actual and evolving needs.

All of the audits and studies that deal with DoD contracting practices come to the same conclusions. And, what applied during the war in Iraq is still the situation. At this point, contracting for services is still not included within a plan or strategy, there is no single responsible institution or inter-agency process to oversee either the awarding or fulfilling of contracts, and oversight personnel are lacking in both numbers and preparation. Currently, based upon the earlier huge reliance on contractors in Iraq and Afghanistan and the unrelenting negative publicity where Blackwater came to symbolize contracting out, the topic of contracting out as the US returns to Iraq is "toxic". The problems have not been resolved, but rather swept under the carpet.

\section{Considerations for other countries}

Once contracting begins, and an industry emerges motivated by the profit motive, employing people, and engaging in lobbying and "strategic communications", it will never go away. What was lacking in the US, and the effort since then has been to catch up, is a robust legal framework, a clear definition of

52 Ibid: Military Operations (no page numbers).

53 Ibid: Military Operations (no page numbers). 
what can and, more importantly, cannot be contracted out, and a robust doctrine, with extensive training for all military personnel on how to deal with contractors. In the US all of these were initially missing, and it is only with great, and inconsistent, efforts that there is any progress at all in their being remedied. If a country can focus on these key requirements from the beginning, before contracting out is well established, then it will have a better chance of minimizing the negative aspects of contracting out. It must always be remembered there is a tension between two different mentalities or world views in that membership in the uniformed services is based on a sense of service and commitment, and PSCs are based on a profit-motive. This contrast can result in tensions in that there may be, and frequently are, armed personnel where one, working for a PSC, is being paid a salary that is three times greater than the uniformed soldier or officer. And, while the uniformed personnel are responsible for all and everything, the PSC is responsible for only what is included in the contract. This tension or contradiction can result in not only misunderstandings, but also recriminations and morale problems.

\section{Conclusion}

Contracting out, including in security is well-established in the US. There are many causes and implications of contracting out. The logic of it makes sense, on the face of it, but as they say, "the devil is in the details". As there are many causes or drivers, a simple decision, should one be forthcoming, to stop contracting out is impossible. Other countries must be aware of the possible negative implications prior to contracting out key roles and missions of their military forces.

\section{Bibliographic references}

Avant, Deborah The Market for Force: The Consequences of Privatizing Security New York: Cambridge University Press, 2005.

Bruneau, Thomas C. Patriots for Profit: Contractors and the Military in U.S. National Security Stanford: Stanford University Press, 2011.

Commission on Wartime Contracting in Iraq and Afghanistan, Transforming Wartime Contracting: Controlling costs, reducing risks dated August 2011 is available at www. wartimecontracting.gov.

Congressional Budget Office (CBO) 'Contractors' Support of U.S. Operations in Iraq' (Washington, D.C.: CBO, August 2008).

Dew, Nicholas and Bryan Hudgens, (2008) The Evolving Private Military Sector: A Survey, 21-22. Published in http://www.acquisitionresearch.org p. 9.

Dunigan, Molly Victory for Hire: Private Security Companies' Impact on Military Effectiveness Stanford: Stanford University Press, 2011. 
Gansler Commission Report 'Urgent Reform Required: Army Expeditionary Contracting,' report of the Commission on Army Acquisition and Program Management in Expeditionary Operations, 31 October 2007.

Gates, Robert M. Duty: Memoirs of a Secretary at War New York: Alfred A, Knopf, 2014.

Light, Paul C. A Government Ill Executed: The Decline of the Federal Service and How to Reverse It Cambridge, Mass: Harvard University Press, 2008.

Luckey, John R., Valerie Bailey Grasso, and Kate M. Manuel, "Inherently Governmental Functions and Department of Defense Operations: Background, Issues, and Options for Congress," CRS Report for Congress, (15 June 2009).

Manuel, Kate M. "Definitions of 'Inherently Governmental Function' in Federal Procurement Law and Guidance,” CRS Report for Congress, (23 December 2014).

Office of the Under Secretary of Defense (Comptroller) 'National Defense Budget Estimated for FY 2013' available at http://comptroller.defense.gov/Portals/45/Documents/defbudget/ fy2013/FY13_Green_Book.pdf

Organization of American States, Report on Citizen Security in the Americas 2012 Washington, DC: OAS Hemispheric Security Observatory (2012).

Schwartz Moshe and Jennifer Church, "Department of Defense's Use of Contractors to Support Military Operations: Background, Analysis, and Issues for Congress," CRS Report for Congress (17 May 2013).

Schwartz, Moshe "Summary" 'Defense Acquisition Reform: Background, Analysis and Issues for Congress' CRS Report for Congress (23 May 2014).

Schwartz, Moshe, Wendy Ginsberg, and John E. Sargent Jr., "Defense Acquisitions: How and Where DOD Spends Its Contracting Dollars. CRS Report for Congress (30 April 2015).

Singer, Peter Corporate Warriors: The Rise of the Privatized Military Industry Ithaca: Cornell University Press, 2003.

Solis, William M. Director, (2006) Defense Capabilities and Management, "MILITARY OPERATIONS: High-Level DOD Action Needed to Address Long-standing Problems with Management and Oversight of Contractors Supporting Deployed Forces" GAO report to Congress (GAO-07-145).

Stanger, Allison One Nation Under Contract: The Outsourcing of American Power and the Future of Foreign Policy New Haven: Yale University Press, 2009.

Under Secretary of Defense for Acquisition, Technology, and Logistics, Performance of the Defense Acquisition System 2014 Annual Report (Washington, D.C.: USD[AT\&l], June 13, 2014, 4. Available at http://www.acq.osd.mil/

SIGIR Final Report, Learning from Iraq, March 2013 available at www.sigir.mil

Walker, David M. Comptroller General of the United States, Before the Subcommittee on Readiness, Committee on Armed Services, House of Representatives, GAO-08-572T: 4-5. (2008). 


\section{Abstract}

The United States has gone further than any country in the "privatization of security". Other countries may find the economic or financial logic in the use of contractors persuasive. The US experience with contracting out security, particularly in Iraq, was problematic, and can serve as a cautionary tale in order that other countries might learn how to avoid the pitfalls.

Keywords: Iraq; privatization; security; USA.

\section{Resumo}

Os Estados Unidos foram mais longe que qualquer outro país na "privatização da segurança". Outros países podem achar a lógica econômica ou financeira do uso de terceirizados persuasiva. A experiência dos EUA na terceirização da segurança, particularmente no Iraque, foi problemática, e pode servir como lição para que outros países aprendam a evitar as armadilhas.

Palavras-chave: Iraque; privatização; segurança; EUA. 